\title{
Impact of Weather Parameter on Early Blight Epidemiology in Tomato Crop
}

\author{
Ekta P. Chothani ${ }^{1}$, H.J. Kapadiya ${ }^{1 *}$, M.F. Acharya ${ }^{2}$ and C.M. Bhaliya ${ }^{1}$ \\ ${ }^{1}$ Department of Plant Pathology, Junagadh Agricultural University, Junagadh-362 001, India \\ ${ }^{2}$ Department of Entomology, Junagadh Agricultural University, Junagadh-362 001, India \\ *Corresponding author
}

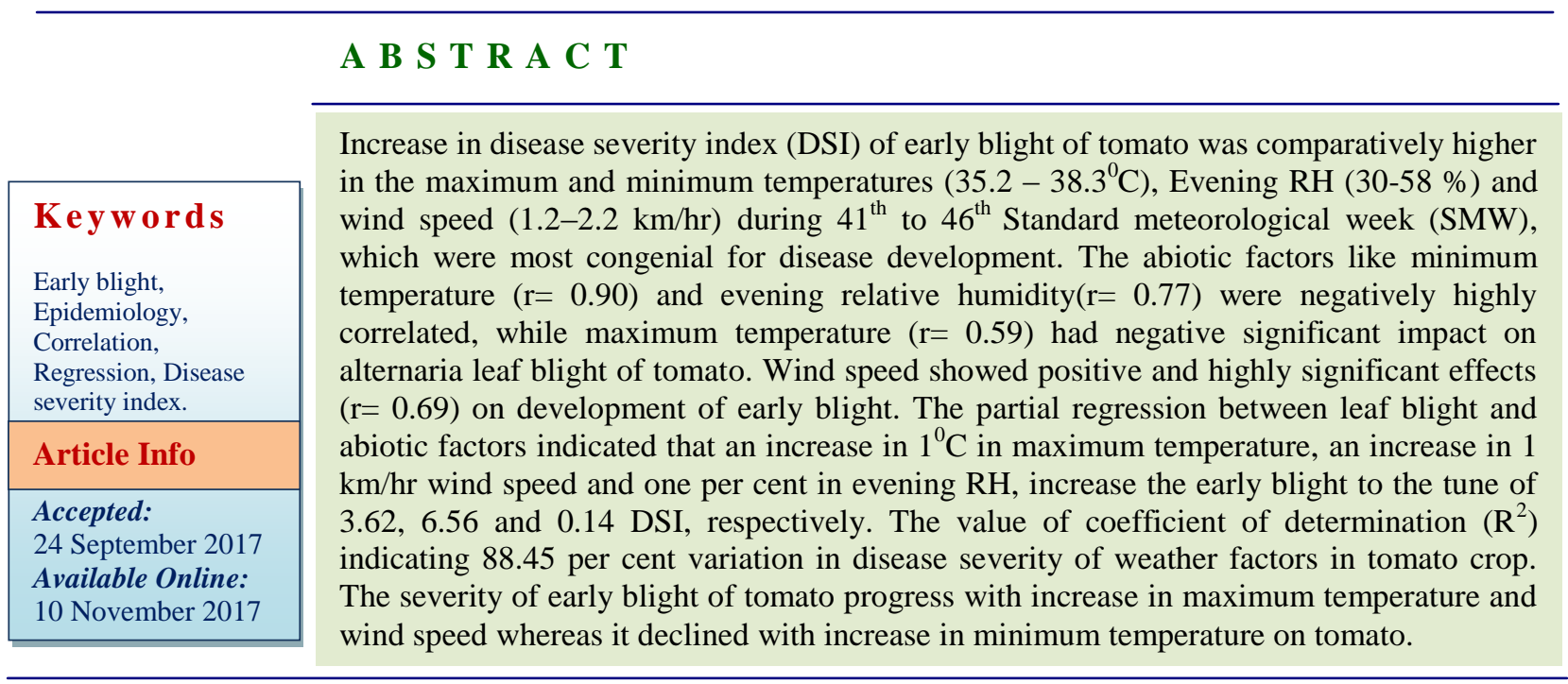

\section{Introduction}

Tomato (Lycopersicon esculentum Mill) regard as poor man's apple. Early blight caused by Alterrnaria solani is one of the world's most catastrophic diseases incurring loss both at pre and post-harvest stages in tomato. Early blight of tomato is economically the most important disease of tomato in USA, Australia, Israel, UK and India, where significant reductions in yield (35\% to $78 \%$ ) have been observed (Datar and Mayee, 1972; Basu, 1974; Jones et al., 1993). Datar and Mayee (1985) reported that $A$. solani caused yield loss of tomato fruit by $78 \%$ at $72 \%$ disease intensity and each $1 \%$ increase in disease intensity reduced tomato yield by $1.36 \%$.
The correlation between weather and disease severity has been recognized by many authors in different parts of the world (Raghavendra, 2006; Sangeetha and Siddaramaiah, 2007; and Devi and Chanu, 2012). Atmospheric Alternaria spores, temperature and humidity are the factors that closely correlate with the occurrence of this disease. With an aim to find out the role of various weather factors on infection and development of early blight in tomato, the study was conducted.

\section{Materials and Methods}

A field experiment was conducted during rabi 2016-17 at Instructional farms of Agronomy, 
JAU, Junagadh (Gujarat tomato-2) variety with large plot technique $(20 \mathrm{~m} \mathrm{x} 1.8 \mathrm{~m})$ in the experiments. The standard method was used for other cultural practices. The disease severity was recorded from 20-tagged plants on 0-5 scale as suggested by Pandey et al., (2003).The disease severity index (DSI) was calculated using the formula (Wheeler, 1969).

Sum of all individual ratings Disease severity index $=$ $\mathrm{x} 100$

No. of leaves examined $x$

Maximum disease scale

The experiment was kept unsprayed for natural development of disease throughout the crop duration. Weekly weather parameters like maximum/minimum temperature $\left({ }^{0} \mathrm{C}\right)$, morning/evening relative humidity (\%), rainfall $(\mathrm{mm})$, rainy days sunshine hours (hr) and wind speed $(\mathrm{km} / \mathrm{hr})$ were studied and recorded from the Department of Meteorology JAU, Junagadh. They were correlated to weekly disease severity index by calculating the Karl person's correlation coefficient (r). Correlation coefficient values were tested individually for their significance at 5 and $1 \%$ probability level using SPSS18.

Further, the data were subjected to multiple liner regression analysis to find out the linearity of the independent variables for prediction of disease. The following prediction equation was used:

$Y=a+b_{1} X_{1}+b_{2} X_{2}+b_{3} X_{3}+b_{4} X_{4}+b_{5} X_{5}+$ $b_{6} X_{6}+b_{7} X_{7}+b_{8} X_{8}$

Where, $\mathrm{Y}$ is the disease severity index, $\mathrm{a}$ is the intercept (constant) $b_{1}$ to $b_{8}$ is the partial regression coefficient associated with each $\mathrm{X}_{\mathrm{i}, \mathrm{i}}=1,2,3,4,5,6,7,8$ are the weather variables, $X_{1}$ is the maximum temperature $\left({ }^{0} \mathrm{C}\right), \mathrm{X}_{2}$ is the minimum temperature $\left({ }^{0} \mathrm{C}\right), \mathrm{X}_{3}$ is the morning relative humidity $(\%), \mathrm{X}_{4}$ is the evening relative humidity $(\%), \mathrm{X}_{5}$ is the rainfall $(\mathrm{mm}), X_{6}$ is the rainy days, $X_{7}$ is the sunshine hours (hr.), $\mathrm{X}_{8}$ is wind speed $(\mathrm{km} / \mathrm{hr})$.

Regression equation for most probable factor (4) is as under.

$Y=a+b_{1} X_{1}+b_{2} X_{2}+b_{3} X_{3}+b_{4} X_{4}$

Where, $\mathrm{Y}$ is the disease severity index, $\mathrm{a}$ is intercept (constant), $b_{1}$ to $b_{4}$ is the partial regression coefficient associated with each $X_{i}$, viz., $\mathrm{X} 1=$ maximum temperature $\left({ }^{0} \mathrm{C}\right), \mathrm{X}_{2}=$ minimum temperature $\left({ }^{0} \mathrm{C}\right), \quad \mathrm{X}_{3}=$ evening relative humidity $(\%), \mathrm{X}_{4}=$ wind speed $(\mathrm{km} / \mathrm{hr})$.

\section{Results and Discussion}

Crop was sown on $1^{\text {st }}$ September 2016 (36 standard week) and early blight appeared during the $40^{\text {th }}$ standard week in tomato crop. Data showed that DSI increased progressively and maximum disease severity index (DSI) of early blight was recorded on the $7^{\text {th }}(62.45 \%)$ standard week.

\section{Progressive disease development}

Disease development under natural conditions was found to be influenced by environmental factors (Table 1). The data from crop seasons revealed that first appearance of early blight was noticed 33 days after planting (DAP) which was recorded on $40^{\text {th }}$ standard meteorological week in 2016-17. So, 36 to 39 SMW data were considered as incubation period of early blight in tomato crop. The development of the disease was initially slow but, it reached to maximum during the $7^{\text {th }}$ SMW $(62.45 \%)$ which happened in the month of February.

During the cropping period maximum temperature showed ranged from $29.1^{\circ} \mathrm{C}\left(51^{\text {st }}\right.$ SMW) to 38.5 (40 ${ }^{\text {th }}$ SMW). Minimum 
temperature ranged from $10.4^{0} \mathrm{C}\left(4^{\text {th }} \mathrm{SMW}\right)$ to $24.7{ }^{0} \mathrm{C}\left(38^{\text {th }} \mathrm{SMW}\right)$. The relative humidity $(\mathrm{RH})$ during morning ranged from $56\left(51^{\text {st }}\right.$ SMW) to 91 ( $38^{\text {st }}$ SMW) per cent and evening RH ranged from $22\left(51^{\text {st }}\right.$ SMW $)$ to $80\left(38^{\text {th }}\right.$ SMW) per cent. However, rainfall was noted to the tune of $0 \mathrm{~mm}$ to $119.8 \mathrm{~mm}$ ( $38^{\text {th }} \mathrm{SMW}$ ); rainy days 0 to 4 ( $\left.38^{\text {th }} \mathrm{SMW}\right)$; sunshine hours ranged from $3.6\left(38^{\text {th }} \mathrm{SMW}\right)$ to $9.8\left(39^{\text {th }}\right.$ SMW) hours and wind speed ranged from 1 to $5.3 \mathrm{~km} / \mathrm{hr}$.

Increase in disease severity index was comparatively higher in the temperature ranged from $35.2-38.3^{\circ} \mathrm{C}$ (maximum) and $17.1-24.4^{0} \mathrm{C}$ (minimum) $26.80-31.35{ }^{0} \mathrm{C}$ average minimum and maximum temperature, 30-58 (Eve. RH) and 1.2-2.2 (wind speed) during $41^{\text {th }}$ to $46^{\text {th }} \mathrm{SMW}$ were most congenial for disease development. These finding are in agreement with the earlier findings (Broker and Patil, 1995; Rajiv Kumar and Singh, 1996; Das et al., 1998 and Kemmitt, 2002, Sahu et al., 2014).

\section{Correlation study}

Correlation coefficient study revealed that, maximum temperature was significant, whereas morning temperature and evening relative humidity highly significant with negative effect on development of early blight. Wind speed showed positive and highly significant effects $(\mathrm{r}=0.69)$ on development of early blight (Table 2).

\section{Regression studies}

During the year 2016-17, the coefficient of multiple determinants $\left(R^{2}\right)$ was 0.9065 indicating $90.65 \%$ of variation in early blight development explained by the set of variable in the study (Table 3). The maximum temperature $\left(\mathrm{X}_{1}\right)$ had positive effect 3.61 increased the development of early blight. This indicated that the increase in temperature by $1^{0} \mathrm{C}$ increased the development of early blight by 3.61\%, during 2016-17.

The multiple liner regression equation was fitted to the data and the equation arrived for the weather parameters was $\mathrm{Y}=3.6775+$ $3.6101 * * \mathrm{X}_{1}-5.4207 * * \mathrm{X}_{2}+0.1712 \mathrm{X}_{3}+$ $0.2721 \mathrm{X}_{4}-0.1959 \mathrm{X}_{5}-1.2276 * * \mathrm{X}_{6}-$ $3.8526 * * \mathrm{X}_{7}+5.6490^{* *} \mathrm{X}_{8}$.

This revealed that when there was increase in one unit of maximum temperature $\left(1^{0} \mathrm{C}\right)$, morning humidity $(1 \%)$, evening $\mathrm{RH}(1 \%)$ and wind speed $(1 \mathrm{~km} / \mathrm{hr}$.), the per cent disease index increase by 3.61, 0.17, 0.27 and 5.64 units, respectively; while when there was increase in one unit of minimum temperature $\left(1^{0} \mathrm{C}\right)$, rainfall $(1 \mathrm{~mm})$, rainy days (1 day) and sunshine hours $(1 \mathrm{hr})$, the per cent disease severity index decreased by $5.42,0.19,1.22$ and 3.85 units, respectively.

There were five weather parameters predicted highly (positive or negative) significant impact on DSI of A. solani. The weather factors influenced the disease incidence to the extent of 90.65 per cent. These finding are in agreement with the earlier finding of Sahu $e t$ al., (2014). Who was noted that the minimum temperature negative highly significant correlation with early blight disease development on both the year.

In order to know the predictive abilities of weather parameters to DSI of early blight, the multiple regression analysis was carried out by taken disease severity index (Y) as dependent variable and weather parameters $(\mathrm{X})$ as independent variable.

Among the eight weather parameters most probable and precise result, four weather parameter that showed significant correlation with DSI or had moderate or very high direct or indirect effect on DSI were considered for multiple regression analysis. 
Table.1 Effect of weather parameters on disease development and severity of early blight of tomato during Rabi 2016-17 at J.A.U. Junagadh

\begin{tabular}{|c|c|c|c|c|c|c|c|c|c|c|c|}
\hline St. Week & $\begin{array}{c}\text { Alt. } \\
\text { blight } \\
\% \\
\end{array}$ & $\begin{array}{l}\text { Increase } \\
\text { in DSI }\end{array}$ & $\begin{array}{c}\text { Maxi } \\
\text { Temp. }{ }^{0} \mathrm{C}\end{array}$ & $\begin{array}{c}\text { Mini Temp. } \\
{ }^{0} \mathrm{C}\end{array}$ & $\begin{array}{c}\text { Morning } \\
\text { RH \% }\end{array}$ & $\begin{array}{c}\text { Evn. RH } \\
\%\end{array}$ & $\begin{array}{c}\text { Rainfall } \\
\text { mm }\end{array}$ & $\begin{array}{c}\text { Rainy } \\
\text { days }\end{array}$ & $\begin{array}{l}\text { Sunshin } \\
\text { e Hr. }\end{array}$ & $\begin{array}{l}\text { Wind } \\
\text { speed }\end{array}$ & $\begin{array}{c}\text { Meaning } \\
\text { daily } \\
\text { temp }\end{array}$ \\
\hline 1 & 2 & 3 & 4 & 5 & 6 & 7 & 8 & 9 & 10 & 11 & 12 \\
\hline 37 & 0.00 & 0.0 & 34.9 & 22.7 & 83 & 56 & 94.5 & 1 & 6.0 & 1.9 & 28.80 \\
\hline 38 & 0.00 & 0.0 & 32.5 & 24.7 & 91 & 80 & 119.8 & 4 & 3.6 & 2.4 & 28.60 \\
\hline 39 & 0.00 & 0.0 & 31.2 & 22.7 & 82 & 66 & 0 & 0 & 9.8 & 2.1 & 26.95 \\
\hline 40 & 1.50 & 1.50 & 38.5 & 24.3 & 75 & 47 & 0 & 0 & 8.4 & 1.3 & 31.40 \\
\hline 42 & 14.90 & 9.65 & 37.2 & 23.7 & 72 & 48 & 0 & 0 & 9.0 & 1.3 & 30.45 \\
\hline 43 & 18.25 & 3.35 & 37.4 & $\Varangle \quad 21.2$ & 64 & 34 & 0 & 0 & 8.9 & 1.2 & 29.30 \\
\hline 44 & 30.51 & 12.26 & 35.2 & 19.6 & 67 & 38 & 0 & 0 & 8.9 & 1.8 & 27.40 \\
\hline 45 & 35.25 & 4.74 & 36.5 & 17.1 & 70 & 30 & 0 & 0 & 8.7 & 2.2 & 26.80 \\
\hline 46 & 42.36 & 7.11 & 35.8 & 19.4 & 66 & 35 & 0 & 0 & 8.4 & 2.2 & 27.60 \\
\hline 47 & 44.52 & 2.16 & 36.4 & 19.4 & 70 & 48 & 0 & 0 & 6.7 & 1.0 & 27.90 \\
\hline 48 & 46.44 & 1.92 & 32.3 & 17.7 & 68 & 33 & 0 & 0 & 6.8 & 5.0 & 25.00 \\
\hline 49 & 47.67 & 1.23 & 33.7 & 14.0 & 66 & 28 & 0 & 0 & 8.1 & 2.5 & 23.85 \\
\hline 51 & 50.45 & 0.66 & 29.1 & 11.2 & 56 & 22 & 0 & 0 & 8.5 & 4.7 & 20.15 \\
\hline 52 & 52.34 & 1.89 & 30.1 & 12.4 & 64 & 31 & 0 & 0 & 8.0 & 4.0 & 21.25 \\
\hline 1 & 53.45 & 1.11 & 31.5 & 13.8 & 74 & 30 & 0 & 0 & 8.3 & 3.2 & 22.65 \\
\hline 2 & 55.45 & 2.00 & 30.2 & 12.3 & 79 & 34 & 0 & 0 & 8.3 & 3.5 & 21.25 \\
\hline 3 & 56.56 & 1.11 & 29.2 & 11.7 & 72 & 33 & 0 & 0 & 8.3 & 4.4 & 20.45 \\
\hline 4 & 57.56 & 1.00 & 29.8 & 10.4 & 75 & 39 & 0 & 0 & 8.9 & 2.7 & 20.10 \\
\hline 5 & 58.67 & 1.11 & 31.4 & 14.6 & 82 & 37 & 0 & 0 & 8.5 & 4.1 & 23.00 \\
\hline 6 & 60.76 & 2.09 & 31.0 & 12.5 & 79 & 34 & 0 & 0 & 9.2 & 3.8 & 21.75 \\
\hline 7 & 62.45 & 1.69 & 30.8 & 16.1 & 73 & 33 & 0 & 0 & 7.1 & 5.3 & 23.45 \\
\hline \multicolumn{3}{|c|}{ Range of diff. weather parameter } & $29.1-38.5$ & - & $56-91$ & $22-80$ & $0-119.8$ & $0-4$ & $3.6-9.8$ & $1-5.3$ & - \\
\hline Total & $\begin{array}{c}844.130 \\
0\end{array}$ & - & 795.9000 & 420.9000 & 1752.0000 & 971.0000 & 224.7000 & 6.0000 & 190.9000 & 68.5000 & - \\
\hline Mean & 35.1721 & - & 33.1625 & 17.5375 & 73.0000 & 40.4583 & 9.3625 & 0.2500 & 7.9542 & 2.8542 & - \\
\hline Sd & 23.3270 & - & 3.0880 & 4.9445 & 8.0163 & 13.6030 & 30.4222 & 0.8470 & 1.2935 & 1.2864 & - \\
\hline $\begin{array}{l}\text { Correlatio } \\
\text { n }\end{array}$ & - & - & -0.5988 & -0.9087 & -0.4321 & -0.7760 & -0.4809 & -0.4528 & 0.2911 & 0.6940 & - \\
\hline SE of $r$ & - & - & 0.1670 & 0.0870 & 0.1880 & 0.1315 & 0.1828 & 0.1859 & 0.1995 & 0.1501 & - \\
\hline Cal t & - & - & 3.5858 & 10.4407 & 2.2979 & 5.9010 & 2.6301 & 2.4358 & 1.4591 & 4.6228 & - \\
\hline
\end{tabular}


Table.2 Correlation coefficient between weather parameters and early blight severity index

\begin{tabular}{|l|l|l|}
\hline Sr. No. & Weather parameters & Correlation coefficient ' $r$ ' value \\
\hline 1 & Maximum temperature & $-0.5988^{*}$ \\
\hline 2 & Minimum temperature & $-0.9087^{* *}$ \\
\hline 3 & Morning relative humidity & -0.4321 \\
\hline 4 & Evening relative humidity & $-0.7760^{* *}$ \\
\hline 5 & Rainfall & -0.4809 \\
\hline 6 & Rainy days & -0.4528 \\
\hline 7 & Sunshine hour & 0.2911 \\
\hline 8 & Wind speed & $0.6940^{* *}$ \\
\hline
\end{tabular}

Significant at $(\mathrm{p}=0.05)$ level $(\mathrm{R}$ value 0.582$), \mathrm{n}=22$ Significant at $(\mathrm{p}=0.01)$ level $(\mathrm{R}$ value 0.663$)$

Table.3 Multiple regression equation for production of Alternaria blight in tomato crop

\begin{tabular}{|l|l|l|}
\hline Sr. No. & Particulars & Regressioncoefficient' $b$ ' value \\
\hline 1 & Constant $($ Intercept $)$ & 3.6775 \\
\hline 2 & Maximum temperature $\left(\mathrm{X}_{1}\right)$ & $3.6101^{* *}$ \\
\hline 3 & Minimum temperature $\left(\mathrm{X}_{2}\right)$ & $-5.4207^{* *}$ \\
\hline 4 & Morning relative humidity $\left(\mathrm{X}_{3}\right)$ & 0.1712 \\
\hline 5 & Evening relative humidity $\left(\mathrm{X}_{4}\right)$ & 0.2721 \\
\hline 6 & Rainfall $\left(\mathrm{X}_{5}\right)$ & -0.1959 \\
\hline 7 & Rainy days $\left(\mathrm{X}_{6}\right)$ & $-1.2276^{* *}$ \\
\hline 8 & Sunshine Hour $\left(\mathrm{X}_{7}\right)$ & $-3.8526^{* *}$ \\
\hline 9 & Wind speed $\left(\mathrm{X}_{8}\right)$ & $5.6490^{* *}$ \\
\hline 10 & R Square $\left(\mathrm{R}^{2}\right)$ & 0.9065 \\
\hline 11 & Adjusted $\mathrm{R}$ Square & 0.8566 \\
\hline
\end{tabular}

Significant at $(\mathrm{p}=0.05)$ level $(\mathrm{R}$ value 0.582$), \mathrm{n}=22$ Significant at $(\mathrm{p}=0.01)$ level $(\mathrm{R}$ value 0.663$)$

Table.4 Regression analysis of disease severity index with meteorological factors

\begin{tabular}{|c|c|c|c|c|c|c|}
\hline No. & $\begin{array}{l}\text { Independe } \\
\text { nt variable }\end{array}$ & Constant $^{\mathbf{6}} \mathbf{a}$ & $\begin{array}{c}\text { Regression } \\
\text { coefficient } \\
\text { 'b' }\end{array}$ & $\begin{array}{c}\text { Multiple } \\
\text { determinati } \\
\text { on ' } \mathbf{R}^{2} \text {, }\end{array}$ & $\begin{array}{c}\text { Std. Error } \\
\text { of Reg. } \\
\text { coeff. }\left(\mathbf{b}_{\mathbf{i}}\right)\end{array}$ & $\begin{array}{c}\text { Std. error } \\
\text { of } \\
\text { Estimate }\end{array}$ \\
\hline \multirow[t]{5}{*}{1.} & \multicolumn{6}{|c|}{ Early blight with maxi. and mini. temperature, evening $R H$, wind speed } \\
\hline & Max. Tem. & \multirow{4}{*}{-19.9733} & $3.6293^{* * *}$ & \multirow{4}{*}{$0.8845^{* *}$} & 1.5619 & \multirow{4}{*}{52.1289} \\
\hline & Mini. Tem. & & $-5.1104 * *$ & & 1.1045 & \\
\hline & Eve. RH & & 0.1402 & & 0.2978 & \\
\hline & Wind speed & & $6.5660^{* * *}$ & & 2.6497 & \\
\hline
\end{tabular}

Based on the multiple regression studies of most probable factor (4) the following equation were fitted for early blight of tomato crop (Table 4). Regression equation is $\mathrm{Y}=-$ $19.97+3.6293 * * \mathrm{X}_{1}-5.1104 * * \mathrm{X}_{2}+0.1402$ $\mathrm{X}_{3}+6.5660 * * \mathrm{X}_{4}, \mathrm{R}^{2}=0.8845$.
The predication equation indicated that an increase in $1{ }^{0} \mathrm{C}$ maximum temperature increase the early blight to the tune of 3.62 DSI. Similarly an increase in $1 \mathrm{~km} / \mathrm{hr}$ wind speed increases the early blight to the tune of 6.56 DSI. Conversely, an increase of $1{ }^{0} \mathrm{C}$ 
minimum temperature reduced the early blight to the tune of 5.11 DSI. The value of coefficient of determination $\left(\mathrm{R}^{2}\right)$ were worked out to the tune of 0.8845 indicating 88.45 per cent variation in disease severity of weather factors during the year 2016-17 in tomato crop (Table 4).

The multiple regression fit was found highly significant for the data with $\mathrm{R}^{2}=0.8845$ for the DSI significance of the coefficient is presented in Table 4 out of four weather parameters selected for study, maximum temperature and wind speed was found to be positive and minimum temperature negative impact on DSI, while evening RH showed non-significant. The present result is corroborate the finding of Champawat and Sharma (2009) they studied the influence of environmental factors such as temperature, relative humidity and rain fall on the development of Alternaria blight of tomato from Rajastan. The similar result were also recorded by Sahu et al., (2014) while working with minimum temperature negative highly significant regression effect with early blight disease development in tomato.

From the results presented, it is very clear that the severity of early blight of tomato progress with increase in maximum temperature and wind speed whereas declined with increase in minimum temperature on severity of early blight of tomato. The $\mathrm{R}^{2}$ value indicated that some unknown factors might be involved in early blight development.

\section{References}

Basu, P.K. 1974. Measuring early blight, its progress and influence on fruit losses in nine tomato cultivars. Canadian Pl. Dis. Survey.54: 45-51.

Borkar, S.G. and B.S. Patil. 1995. Chemical control of purple blotch of onion. Indian J. Mycol. Plant Path. 25: 289-290.
Champawat, R.S. and R.S. Sharma. 2009. Influence of temperature, relative humidity and rainfall on Alternaria blight of tomato. J. Mycol. Plant Pathol.39: 550.

Das, N.D., G.R.M. Sankar and N.N. Srivastav. 1998. Studies progression of Alternaria blight disease Alternaria helianthi (Hansf.) Tubaki and Nishihara of sunflower, Ann. Plant. Sci.6:209-211

Datar, V. V. and Mayee, C. D. 1985. Chemical management of early blight of tomato. J MahaAgri Univ., 10(3): 278280.

Datar, V.V. and C.D. Mayee. 1972. Conidial dispersal of Alternaria solani in tomato. Indian Phytopathology. 35: 68-70.

Devi, A.P. and L.B. Chanu. 2012. Airspora and epidemiology of early blight of tomato caused by Altemaria solani (Ell and Mart) Jones and Grant in Manipur. Journal of Mycopathological Research. 50(1): 81-84.

Jones, J.B.,J.P. Jones, R.E. Stall and T.A. Zitter. 1993. Compendium of tomato diseases. St Paul: American Phytopath. Society. 5(1):115-119.

Kemmitt, G. 2002. Early blight of potato and tomato. The Plant Health Instructor. DOI: 10.1094/PHI-I-2002-0809-01.

Pandey, K.K., P.K. Pandey, G. Kalloo and M.K. Banerjee.2003. Resistance to early blight of tomato with respect to various parameters of disease epidemics. $J$. Gen.Plant Pathology.69:364-371.

Raghvendra, K.M. 2006. Epidemiology and management of Alternaria blight of sunflower caused by Alternaria helianthi (Hansf.) Tubaki and Nishihara: University of Agricultural Sciences, Dharwad Ph. D. thesis. Pp.113-118.

Rajivkumar and S.B. Singh. 1996. Influence of weather factors on Alternaria leaf spot development in sunflower. Indian J. Mycol. and Plant Pathol.26: 196-198. 
Sahu, D.K., C.P. Khare, H.K. Singh, R. Patel, and M.P. Thakur. 2014. Epidemiological studies on early blight disease of tomato, The Bioscience.9 (3): 1345-1350.

Sangeetha, C.G. and A.L. Siddaramaiah. 2007. Epidemiological studies of white rust, downy mildew and Alternaria blight of Indian mustard (Brassica juncea (Linn.) Czern. And Coss.). Afr. J. Agric. Res.2 (7): 305-308.

Wheeler, B.E.J. 1969. An Introduction to Plant Diseases. J. Wiley and Sons Limited.

\section{How to cite this article:}

Ekta P. Chothani, H.J. Kapadiya, M.F. Acharya and Bhaliya, C.M. 2017. Impact of Weather Parameter on Early Blight Epidemiology in Tomato Crop. Int.J.Curr.Microbiol.App.Sci. 6(11): 3160-3166. doi: https://doi.org/10.20546/ijcmas.2017.611.370 